\title{
The Influences of Push and Pull Factors on the International Leisure Tourists' Return Intention to Ho Chi Minh City, Vietnam - A Mediation Analysis of Destination Satisfaction
}

\author{
Mai Ngoc Khuong and Huynh Thi Thu Ha
}

\begin{abstract}
The purpose of this research was to examine empirically the causal relationships among push and pull travel motivations, destination satisfaction and return intention of international leisure tourists in Ho Chi Minh City, Vietnam. The research conceptual framework and hypotheses were constructed, based on previous theoretical and empirical studies. A questionnaire survey was conducted with 426 respondents to collect the primary data. Multiple regression and Path analyses were conducted to test the research hypotheses. As a result, push and pull factors had directly positive influences on tourist's return intention to Vietnam. In addition, the results also showed that push and pull factors were indirectly affected tourist's return intention through their destination satisfaction. Consequently, business organizations working in the tourism sector should take into account the essential roles of push and pull factors, in order to attract more potential visitors, enhance their destination satisfaction and encourage them to re-visit Vietnam.
\end{abstract}

Index Terms-Travel motivation, push and pull factors, destination satisfaction, return intention.

\section{INTRODUCTION}

Tourism - "the smokeless industry", is one of the most essential multinational business activities in the world, brings appreciate $30 \%$ of the world's exports of services and has become the major income of many countries. Vietnam is one of the most attractive tourist destinations in Asia and the Pacific area. According to Vietnam General Statistics Office [1], the total international arrivals coming to Vietnam reached 7,572,352 in 2013, increasing $10.6 \%$ over the previous year, with 4,640,882 leisure tourists and accounted for more than $60 \%$. The total revenue of Vietnam tourism industry in 2013 was more than US $\$ 9.5$ billion, increasing 25\% compared to 2012 [2]. Ho Chi Minh City is one of the most popular destinations in Vietnam. The number of international visitors to this city accounted for $55 \%$ of those to Vietnam.

In 2014, Vietnam tourism plans to attract and serve 8 million foreign visitors and gain US\$ 11 billion in total revenue. In order to reach this target, Vietnam tourism organizations need to not only attract more first-time tourists, but also increase the number of repeat visitors, and make Vietnam become a loyal destination of international

Manuscript received June 8, 2014; revised August 14, 2014.

Mai Ngoc Khuong and Huynh Thi Thu Ha are with the School of Business, International University - VNU-HCM, Vietnam (e-mail: mnkhuong@hcmiu.edu.vn, hahuynh231@gmail.com). customers.

In tourism destination management, enhancing tourists' satisfaction levels and return intention are extremely crucial and necessary. A number of previous conceptual and empirical studies found that travel motivation, including internal or psychological forces (push factor) and external forces of the destination attributes (pull factor), is the fundamental reason to explain a particular traveling behavior of tourists, the causal relationship among tourists' motivation, satisfaction and post-purchase intention, as well as confirming the vital role of understanding travel motivation in order to enhance their satisfaction and return intention [3]-[9].

The objective of this study was to understand travel motivation of international leisure tourists in Ho Chi Minh City and examine how push and pull travel motivations explain and predict destination satisfaction and return intention to Vietnam. Thereby, this study provided practical evidences about the essential roles of push and pull factors, as well as proposed constructive recommendations to Vietnamese destination managers developing tourism strategies and plans, to enhance the level of satisfaction of international tourists and encourage them to return to Vietnam in the near future.

\section{LITERATURE REVIEW}

\section{A. Travel Motivation}

Motivation is one of the main driving forces used to interpret the behavior of an individual. It contributes to explain why an individual does something, not others. In the tourism context, travel motivation is defined as "a set of attributes that cause a person to participate in a tourist activity" [10] in order to achieve his or her goals and expecting satisfaction [11]-[13]. It is considered as the starting point and one of the most important psychological influences to understand tourist behavior.

Travel motivation is influenced by two forces - the concepts of Push and Pull factors [14], [15]. This concept has become one of the most popular and useful frameworks to study and analyze tourist behavior. Those two factors explain people travel because they are pushed by their own internal forces and pulled by the external forces of destination attributes.

Push motivation is the factors that motivate or create the intangible or intrinsic desires of the individual travelers to go on a vacation [16]-[18]. According to [16], the push factor consists of seven socio-psychological motives (escape, 
self-exploratory, relaxation, prestige, regression, kinship enhancement, and social interaction) and two cultural motives (novelty and education). These push factors are recognized as the first step and useful tool in explaining the desire for travel and understanding tourists' behavior [16].

Pull motivation, on the other hand, is the tangible resources and traveler's perception and expectation towards the features, attractions, or attributes of a specific destination; therefore, it plays an important role in destination choice of tourists once the decision to travel has been made [16], [17], and [19]. Pull factor is the external forces related to natural and historic attractions, food, people, recreation facilities, and marketed image of the destination [17].

Ref. [6], [15], and [20] showed that push and pull travel motivations are not independent, but related to each other. Whereas push factors refer to the forces that push individuals from home and make decision to travel, pull factors simultaneously pull them toward a specific destination. Thus, destination marketers and promoters in the tourism industry should keep in mind about the importance of travel motivations, and give more marketing efforts to matching the main attributes of a destination with the needs and expectations of potential customers [21], [22].

\section{B. Destination Satisfaction}

Different from other business activities, tourism is a business of selling memorable experiences. Tourist satisfaction is "the extent of overall pleasure or contentment felt by the visitor, resulting from the ability of the trip experience to fulfill the visitor's desires, expectations and needs in relation to the trip" [23]. It is the mental evaluation and comparison between what customers expected to receive and what they actually receive [24]. In specific, tourists' destination satisfaction is based on the comparison of their pre-travel expectations and images about the destination and their post-travel experiences at this destination [25]-[27]. While destination expectations are formed by visitors' past experience, recommendation of friends and family, tourist information and promises of destination marketers [28], tourists' real experiences are based on what they see, feel, and achieve at this destination [3]. Based on the expectationdisconfirmation theory [29], if the actual performance is better than customers' expectation, this leads to positive disconfirmation and high satisfaction; on the other hand, if the actual performance is worse than their expectations, this leads to negative disconfirmation and dissatisfaction.

In the tourism destination management, tourists' destination satisfaction is the most essential element for the sustainable development of business. Many previous studies provided empirical evidences in the significant relationship between tourists' satisfaction and their intention to revisit and recommend the destination to other potential customers [30]-[33].

\section{Return Intention}

The concept of return intention comes from behavioral intention, which is defined as "an anticipated or planned behavior in the future" [34], [35]. It is the most proximate measurement and powerful tool to understand and predict social behavior [36], [37]. It has been associated with actual observed behavior [38] and once the intention is settled, the behavior will be taken followed [39].

In the tourism and recreation sectors, return intention is the tourist's judgment about the likeliness to re-visit a destination or attraction. In fact, because travel destination is considered as a special kind of product that possesses natural resources, artificial attractions, or cultures [6], the customers' intention to come back to a foreign land again is much lower than other kinds of common product, even if this destination meets their needs and expectations. Tourists tend to choose other places that they have not visited before in order to seek new experiences at new destinations [40].

Return intention, together with recommend intention are the main components of destination loyalty. Repeat visitors not only provide a constant source of income and revenue for the tourist destination, increase market share, generate positive word of mouth, but also minimize the costs of destination marketing and operation [41]-[43]. Thus, tourist destination managers need to concern in their guests' intention to re-visit as one of the fundamental issues [9].

\section{The Proposed Hypothetical Model}

There are a variety of conceptual and empirical researches have proved the direct and indirect influence of destination satisfaction on destination loyalty/return intention, as well as the causal relationships among travel motivation, destination satisfaction, and return intention. Fig. 1 illustrates the hypothetical causal model of this study, which was applied from previous hypothesized models of [3]-[9].

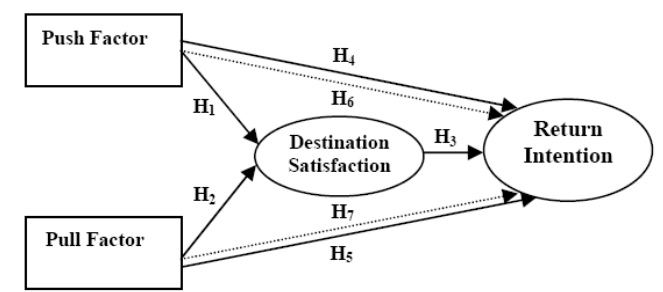

Fig. 1. Proposed hypothetical model.

- $\mathrm{H}_{1}$ : Push factor is hypothesized to positively and directly affect tourists' destination satisfaction.

- $\mathrm{H}_{2}$ : Pull factor is hypothesized to positively and directly affect tourists' destination satisfaction.

- $\mathrm{H}_{3}$ : Destination satisfaction is hypothesized to positively and directly affect tourists' return intention to Vietnam.

- $\mathrm{H}_{4}$ : Push factor is hypothesized to positively and directly affect tourists' return intention to Vietnam.

- $\mathrm{H}_{5}$ : Pull factor is hypothesized to positively and directly affect tourists' return intention to Vietnam.

- $\mathrm{H}_{6}$ : Push factor is hypothesized to indirectly affect tourists' return intention to Vietnam through destination satisfaction.

- $\mathrm{H}_{7}$ : Pull factor is hypothesized to indirectly affect tourists' return intention to Vietnam through destination satisfaction.

\section{Methodology}

\section{A. Questionnaire Design and Data Collection}

In this study, quantitative data collection method was 
applied to analyze the empirical data which were collected from the responses through using questionnaire survey. The measure was based on a five-point Likert scale with anchors ranging from "1 - Strongly Disagree" to "5 - Strongly Agree".

The target population of this study is those foreign leisure tourists in Ho Chi Minh City during the period surveyed, on March and April, 2014. All respondents were approached personally at Tan Son Nhat International Airport, Sai Gon Station, and various tourist attractions in the center of Ho Chi Minh City, such as Ben Thanh Market, the Unification Palace, Museum of War Remnant, Saigon Notre-Dame Basilica Church, Saigon Central Post Office, Saigon Opera House, September 23 Park, Pham Ngu Lao Street, Bui Vien Street, etc.

The Pilot Test with $N=20$ was conducted to clarify the meanings of the survey's questions and ensure the understanding for respondents. After modification, there were total 426 cases in good quality collected within two months and analyzed for further research results.

\section{B. Data Analysis}

The study used SPSS (Statistical Package for the Social Sciences) statistical software version 20.0 to analyze the data. First, Exploratory Factor Analysis (EFA) and Reliability Test were conducted to identify the interrelationships among a set of research variables and to ensure the reliability and validity of them. Subsequently, Multiple Regression and Path Analysis were employed to explore the causal relationships among variables, and then conclude in the research hypotheses.

\section{Factor Analysis and Reliability}

TABLE I: FACTOR ANALYSIS AND RELIABILITY COEFFICIENTS OF INDEPENDENT VARIABLES

\begin{tabular}{|c|c|c|}
\hline Variables & $\begin{array}{l}\text { Factor } \\
\text { Loadings }\end{array}$ & $\begin{array}{l}\text { Cronbach's } \\
\text { Alpha }\end{array}$ \\
\hline Push factor (PUSH) & & .705 \\
\hline To learn something new and interesting & .793 & \\
\hline $\begin{array}{l}\text { To visit a place that I have not visited } \\
\text { before }\end{array}$ & .773 & \\
\hline $\begin{array}{l}\text { To fulfill my dream of visiting a foreign } \\
\text { land/country }\end{array}$ & .682 & \\
\hline $\begin{array}{l}\text { To meet new people and socialize with } \\
\text { local community }\end{array}$ & .650 & \\
\hline To escape from daily routine & .410 & \\
\hline Pull factor (PULL) & & .700 \\
\hline $\begin{array}{l}\text { Good physical amenities: } \\
\text { accommodation, transportation, and } \\
\text { recreation facilities }\end{array}$ & .715 & \\
\hline Festival/special events and activities & .682 & \\
\hline Warm and sunny weather & .587 & \\
\hline $\begin{array}{l}\text { Historical, cultural, art, and religious } \\
\text { attractions }\end{array}$ & .539 & \\
\hline Variety of food & .532 & \\
\hline $\begin{array}{l}\text { Beautiful natural scenery and landscape: } \\
\text { beaches, forests, mountains, etc. }\end{array}$ & .490 & \\
\hline Safe and easy access destination & .471 & \\
\hline
\end{tabular}

For this study, two exploratory factor analyses (EFA) were conducted with Kaiser-Meyer-Olkin and Barltlett's test of sphericity, and Varimax Rotation of 17 items of independent variables and 15 items of dependent variables. As the results, the KMO measure of sampling adequacy for both groups of independent $(\mathrm{KMO}=.787)$ and dependent variables $(\mathrm{KMO}=.834)$ were greater than the minimum value for a good factor analysis .60 [44]. In addition, Barltlett's test of sphericity was significant (Sig.=.000), indicating the sufficient correlation between the variables.

Table I above shows the result of independent variables, which was grouped into 2 components (PUSH and PULL). All of the factor loadings of remaining items meet the minimum requirement (.40) [45], ranging from .410 to .793. The Cronbach's alpha values used to estimate the internal consistency between items in each factor were .705 and .700 . According to Pallant (2007), the Cronbach's coefficient alpha value above .60 is considered acceptable, while the more acceptable value should exceed .70 [46].

Similarly, the factor loadings of remaining dependent items ranged from .464 to .780 , divided into 2 groups (DS and RI). The Cronbach's coefficient alpha values were .768 and .721, as shown in Table II.

TABLE II: FACTOR ANALYSIS AND RELIABILITY COEFFICIENTS OF DEPENDENT VARIABLES

\begin{tabular}{|c|c|c|}
\hline Variables & $\begin{array}{l}\text { Factor } \\
\text { Loadings }\end{array}$ & $\begin{array}{l}\text { Cronbach's } \\
\text { Alpha }\end{array}$ \\
\hline Destination satisfaction (DS) & & .768 \\
\hline $\begin{array}{l}\text { In general, I am satisfied with my decision } \\
\text { to visit Vietnam }\end{array}$ & .760 & \\
\hline $\begin{array}{l}\text { My choice to visit Vietnam was a wise one } \\
\text { and worth my time and effort }\end{array}$ & .734 & \\
\hline $\begin{array}{l}\text { I am satisfied with the natural scenery and } \\
\text { environment in Vietnam }\end{array}$ & .599 & \\
\hline $\begin{array}{l}\text { I am satisfied with the culture, history and } \\
\text { art in Vietnam }\end{array}$ & .595 & \\
\hline The visit was exactly what I expected & .586 & \\
\hline $\begin{array}{l}\text { I am satisfied with affordable price in } \\
\text { Vietnam }\end{array}$ & .567 & \\
\hline $\begin{array}{l}\text { I am satisfied with safety and security in } \\
\text { Vietnam }\end{array}$ & .496 & \\
\hline I am satisfied with local cuisine & .464 & \\
\hline Return intention (RI) & & .721 \\
\hline $\begin{array}{l}\text { In general, I will definitely return to } \\
\text { Vietnam in the near future }\end{array}$ & .780 & \\
\hline $\begin{array}{l}\text { Vietnam remains my first choice, if I } \\
\text { travel to Southeast Asia again }\end{array}$ & .741 & \\
\hline $\begin{array}{l}\text { I will keep contact with the people that I } \\
\text { know in Vietnam for the next time I visit }\end{array}$ & .728 & \\
\hline $\begin{array}{l}\text { I will try more tourist products and } \\
\text { services in Vietnam in the future }\end{array}$ & .600 & \\
\hline
\end{tabular}

\section{RESEARCH FINDINGS}

\section{A. Profile of the Sample}

TABLE III: PERSONAL INFORMATION $(N=426)$

\begin{tabular}{|c|c|c|}
\hline & Frequency & Percentage \\
\hline \multicolumn{3}{|l|}{ Gender } \\
\hline Male & 238 & 55.9 \\
\hline Female & 188 & 44.1 \\
\hline \multicolumn{3}{|l|}{ Age group } \\
\hline$<18$ & 8 & 1.9 \\
\hline $18-25$ & 123 & 28.9 \\
\hline $26-30$ & 123 & 28.9 \\
\hline $31-40$ & 66 & 15.5 \\
\hline $41-50$ & 48 & 11.3 \\
\hline $51-60$ & 38 & 8.9 \\
\hline
\end{tabular}




\begin{tabular}{lcc}
$>60$ & 20 & 4.7 \\
\hline Country & 99 & 23.2 \\
Asia & 93 & 21.8 \\
US/Canada & 100 & 23.5 \\
Australia/NZ & 134 & 31.5 \\
Europe & & \\
\hline Relationship Status & 284 & 66.7 \\
Single & 142 & 33.3 \\
$\quad$ Married & \\
\hline \hline
\end{tabular}

TABLE IV: TRAVEL INFORMATION $(N=426)$

\begin{tabular}{lcc}
\hline \hline & Frequency & Percentage \\
\hline Number of visits to Vietnam & 315 & 73.9 \\
1 & 60 & 14.1 \\
2 & 24 & 5.6 \\
3 & 27 & 6.3 \\
4 or more & & \\
\hline Party Composition & 92 & 21.6 \\
Alone & 334 & 78.4 \\
With others (friends and/or & & \\
family) & & \\
\hline Travel mode to Vietnam & 352 & 82.6 \\
Self-organized & 74 & 17.4 \\
Organized by tourist agency & & \\
\hline Length of stay in Vietnam this & & \\
time & 82 & 19.2 \\
1 - 5 days & 84 & 19.7 \\
6 - 10 days & 76 & 17.8 \\
11 - 15 days & 38 & 8.9 \\
16 - 20 days & 45 & 10.6 \\
21 - 25 days & 54 & 12.7 \\
$25-30$ days & 19 & 4.5 \\
$1-2$ months & 15 & 3.5 \\
$2-3$ months & 13 & \\
$>3$ months & & \\
\hline \hline
\end{tabular}

\section{B. Factors Affecting Destination Satisfaction and Return} Intention

Pearson's Correlation Analysis and Liner Regression Analysis were applied in order to find out the relationship among variables.

Table V illustrates that there were positive correlations between two independent variables (PUSH and PULL), the mediate variable (DS), and the dependent variable (RI). This means that the stronger Push and Pull travel motivations the travelers had, their higher Destination satisfaction and Return intention degree to Vietnam in the future.

TABLE V: CORRELATIONS BETWEEN VARIABLES

\begin{tabular}{|c|c|c|c|c|}
\hline & RI & 1 & 2 & 3 \\
\hline 1. PUSH & $.307^{* *}$ & & & \\
\hline 2. PULL & $.452^{* *}$ & $.390^{* *}$ & & \\
\hline 3. DS & $.478^{* *}$ & $.479^{* *}$ & $.543^{* *}$ & \\
\hline Mean & 3.57 & 4.07 & 3.68 & 4.14 \\
\hline S.D. & .775 & .711 & .571 & .511 \\
\hline
\end{tabular}

- H1: Push factor is hypothesized to positively and directly affect tourists' destination satisfaction.

- H2: Pull factor is hypothesized to positively and directly affect tourists' destination satisfaction.

The result of the data revealed that there were significant positive relationships between the mediate variable of DS and the independent variables: PUSH $(r=.479, p<.01)$ and PULL $(r=.543, p<.01)$. The regression coefficient of PUSH and PULL were $\beta=.226, p=.000$ and $\beta=.376, p=.000$ respectively. This implied that Push and Pull factors had positive effects on Destination satisfaction at the $99 \%$ confidence level. Furthermore, Push and Pull factors could explain $37.9 \%$ the variation of Destination satisfaction $\left(R^{2}=.379\right)$.

- H3: Destination satisfaction is hypothesized to positively and directly affect tourists' return intention to Vietnam.

There was a positive correlation between the mediate variable (DS) and the dependent variable (RI) with $r=.478$, $p<.01$. The coefficient of determination $(\beta=.725, p=.000)$ indicated the relatively strong influence of Destination satisfaction on Return intention at the $99 \%$ confidence level. The $\mathrm{R}$ squared value was .228 , which means $22.8 \%$ the variation of Return Intention can be explained by Destination satisfaction.

- H4: Push factor is hypothesized to positively and directly affect tourists' return intention to Vietnam.

- H5: Pull factor is hypothesized to positively and directly affect tourists' return intention to Vietnam.

The Pearson correlation analysis results also showed the positive correlations between two independent variables (PUSH and PULL) and the dependent variable (RI), with $r=.307, p<.01$ and $r=.452, p<.01$ respectively. Return Intention is directly affected by Push factor $(\beta=.168, p=.001)$ and Pull factor $(\beta=.532, p=.000)$ in the positive direction and at the $99 \%$ confidence level. The $R^{2}=.225$ implied that the Push and Pull factors can explain $22.5 \%$ the variation of Return intention.

\section{Indirect Effects of Return Intention}

The indirect effect of an independent variable on the dependent variable through the mediate one is the total product of the effect of that independent variable on the mediate variable and the effect of the mediate variable on the dependent variable [47].

- H6: Push factor is hypothesized to indirectly affect tourists' return intention to Vietnam through destination satisfaction.

- H7: Pull factor is hypothesized to indirectly affect tourists' return intention to Vietnam through destination satisfaction.

As mentioned, Destination satisfaction was positively affected by Push factor $(\beta=.226, p=.000)$ and Pull factor $(\beta=.376, p=.000)$. These two factors directly influenced the mediate variable of Destination satisfaction $\left(\mathrm{H}_{1}\right.$ and $\left.\mathrm{H}_{2}\right)$ and then Destination satisfaction directly caused an effect on Return intention with $\beta=.725, p=.000\left(\mathrm{H}_{3}\right)$. Consequently, through the mediate variable of Destination satisfaction, Push and Pull factors created indirect effects on Return intention. Therefore, this research concluded that the stronger Push and Pull travel motivations would lead to the higher Destination satisfaction and Return intention.

\section{Significance of the Indirect Effects}

Table VI shows the results of the bootstrapping method recommended by [47] to test the significance of indirect effects or mediations. The output provided the bootstrapped confidence intervals (at the 95\%). If there is a ZERO (0) lies within the interval range between the lower boundary (LL) 
and the upper boundary (UL), then we can conclude that, with $95 \%$ confidence, there is no mediation or indirect effect. On the other hand, if zero does not occur between the LL and the UL, then we can conclude that, with $95 \%$ confidence, the mediation or indirect effect is significant [48]. As can be seen in the output of Table VI, the indirect effects of PUSH and PULL on RI through the mediation of DS were estimated to lie between .1622 (LL) and .3020 (UL), and .1626 (LL) and .3396 (UL) with $95 \%$ confidence, respectively. Because zero is not in the $95 \%$ confidence interval, we can conclude that the indirect effects of PUSH and PUSH on RI were indeed significantly different from zero at $p<.05$ (two tailed) and the mediation of DS in this study was true.

TABLE VI: DIRECT, INDIRECT AND TOTAL CAUSAL EFFECTS

\begin{tabular}{cccccc}
\hline \hline \multirow{2}{*}{ Variables } & \multicolumn{3}{c}{ Causal Effects } & \multirow{2}{*}{ LL } & UL \\
\cline { 2 - 4 } & Direct & Indirect & Total & & \\
\hline PUSH & .168 & .164 & .332 & .1622 & .3020 \\
PULL & .532 & .273 & .805 & .1626 & .3396 \\
DS & .725 & --- & .725 & & \\
\hline TOTAL & 1.425 & .437 & 1.862 & & \\
\hline \hline
\end{tabular}

\section{E. The Causal Effects of Return Intention}

Table VI summarized the total effects of independent variables, including direct and indirect effects, and mediate variable on Return intention. As regards the total effects was shown, PULL had the strongest impact on RI $(\beta=.805)$, followed by DS $(\beta=.725)$. PUSH had the weakest effect on RI to Vietnam with $\beta=.332$ only. The total effect of these factors on Return Intention was 1.862, in which direct effects of factors of PUSH, PULL, and DS accounted for more than $75 \%$ while indirect effects made up nearly $25 \%$.

\section{F. Path Diagram}

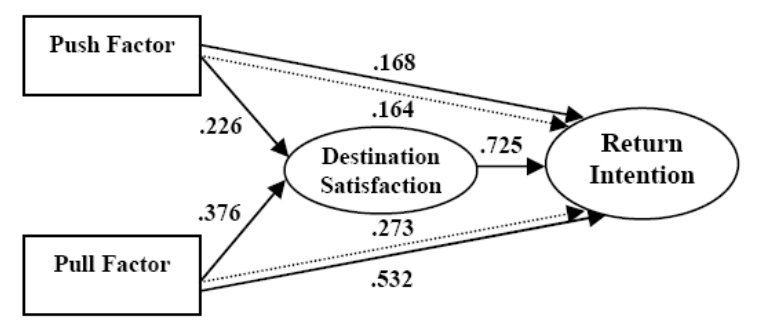

Fig. 2. Path coefficients of the structural equation for hypothesis testing.

\section{DISCUSSIONS AND RECOMMENDATIONS}

\section{A. Discussions}

The empirical results of this study supported the proposed model which provided a good quality of the research conceptual framework to positively explain and predict intention to re-visit Vietnam destination of international leisure tourists in Ho Chi Minh City, Vietnam. The statistical findings showed that Push and Pull factors did not only directly affect Return intention, but also had indirect impacts on Return intention through Destination satisfaction. This means that when travelers have stronger intrinsic desires to go on a vacation and perception towards the features, attractions, or attributes of a specific destination, they may get higher satisfaction about this destination as well as higher intention to re-visit it in the future.

This finding was supported by some previous researches of [5]-[9]. They agreed that travel motivation, including internal or psychological motives (Push factor) and external motives of the destination attribute (Pull factor) positively affected tourist satisfaction of destination, as well as their return intention to this place in the future.

However, in the study of [3], they found out some significant differences. In their findings, the relationship between Push travel motivation and Satisfaction was not supported by the data. Moreover, they indicated the negative influence of Pull travel motivation on Satisfaction, which was contrary to this research finding as the positive influence. Finally, Destination loyalty, consisting of Recommendation and Revisiting, was positively and directly influenced by Push motivation, but there is no relationship with Pull motivation.

Furthermore, this research findings indicated that Pull factor had more significant effect on tourists' destination satisfaction and their return intention than Push factor. Therefore, it was concluded that the external forces of Vietnam attributes are more important than tourists' internal and psychological forces in enhancing satisfaction and return intention. In another word, their satisfaction and return intention degrees to a certain destination are much depended on how well they perceive about this destination image, rather than their own personal wants and needs.

In summary, the empirical results of this study about the causal relationship between Push, Pull factors, Destination satisfaction and Return intention are summarized and presented in Table VII below. All research hypotheses were supported and accepted; therefore, they provided tenable evidences that the research's conceptual framework was considered statistically acceptable in the Vietnam tourism market.

TABLE VII: RESULTS OF THE RESEARCH'S HYPOTHESES

\begin{tabular}{lllll}
\hline \hline \multicolumn{2}{c}{ Hypotheses } & Beta & Sig. & Results \\
\hline H1: PUSH $\rightarrow$ DS & & .226 & .000 & Accepted \\
H2: PULL $\rightarrow$ DS & & .376 & .000 & Accepted \\
H3: DS $\rightarrow$ RI & & .725 & .000 & Accepted \\
H4: PUSH $\rightarrow$ RI & & .168 & .001 & Accepted \\
H5: PULL $\rightarrow$ RI & & .532 & .000 & Accepted \\
H6: PUSH $\rightarrow$ DS $\rightarrow$ RI & .164 & .000 & Accepted \\
H7: PULL $\rightarrow$ DS $\rightarrow$ RI & .273 & .000 & Accepted \\
\hline \hline
\end{tabular}

\section{B. Recommendation for Ho Chi Minh City Tourism}

The findings of this research proposed some constructive recommendations for business organizations working in the tourism sector, destination marketers and managers in Ho Chi Minh City in specific and in Vietnam in general.

First, based on the empirical research findings, this study provided practical evidences on the causal relationships between travel motivation, destination satisfaction and return intention to Vietnam of foreign leisure tourists; in order to increase the awareness of tourism organizations about the role of push and pull factors and their positive influences on tourist's satisfaction and intention to re-visit Vietnam. They should pay attention on both intrinsic and extrinsic reasons why people make decision to travel, and their needs and 
expectations about that trip as well. Thereby, Vietnam destination marketers can design efficient marketing strategies and tools to attract more potential visitors. They should invest in impressive tourism advertisements and attractive promotional programs to raise potential customers' travel motivation. Investing in social media, especially tourism websites and video clips with a variety of tourist information and images are also effective ways to introduce the "timeless charm" of Vietnam destination for foreigners.

Second, tourism companies should take into consideration to diversify vacation packages and develop destination programs and activities to provide more different choices for tourists. Based on the travel motivations of each group of visitors, they need to be flexible in designing and serving their products and services offering to customers, adapt and/or adjust them as well as prepare for the alternatives to meet the different demands of different customers. Therefore, tourist providers can increase their tourists' satisfaction and/or reduce the risk of dissatisfaction, and offer interesting and unforgettable tourism experiences for them. Putting more efforts to train employees is necessary in order to enhance their performance in the way of delivering services to customers. A qualified employee is not only expert in foreign languages and tourism knowledge, but also has flexible problem-solving skills to serve customers in their interest.

In addition, regarding to the essential missions of destination managers, they need to be concerned in improving both quantity and quality of tourist attractions and infrastructure, such as conserving and protecting natural, historical and cultural attractions, national identity and value, organizing more festivals and special events, upgrading physical amenities, etc. Many issues related to environmental pollution, traffic jams, pickpocket and robbery, stalking hawkers, or poor quality souvenirs have to be controlled and eliminated. Thus, Vietnam tourism will enhance its destination image in the eyes of international friends and become more and more attractive rather than other tourism destinations.

Last but not least, government also plays a large role in the development of tourism industry. Vietnam government should propose and issue constructive policies to attract foreign visitors and support for tourist providers. In Thailand and Cambodia, for instance, since their governments allowed on-the-spot visas at the border for tourists, the number of international arrivals has increased significantly. That is one of tourism development policies that Vietnam government should notice and experience.

\section{CONCLUSION}

This study intended to identify travel motivation of international leisure tourists in Ho Chi Minh City and investigate the causal relationships among the push and pull travel motivations, destination satisfaction and return intention. Based on previous theoretical and empirical studies, the research conceptual framework and hypotheses were constructed. After analyzing collected data, all proposed hypotheses and model were accepted and this research's objectives have been successfully obtained. From this research findings, it can be concluded that both push and pull travel motivations have significant and positive influence on tourist's destination satisfaction and then, intention to re-visit. Push and pull factors are the effective tools to explain and predict destination satisfaction and return intention of them. Therefore, business organizations working in the tourism sector in Ho Chi Minh City in specific and in Vietnam in general should take into account the essential roles of push and pull factors, in order to understand and respond tourists' demands and expectations when they travel to Vietnam. The results of this research can be used as valuable and accurate information for destination marketers and managers to implement strategies and plans, to not only attract more potential visitors, but also enhance their destination satisfaction and encourage them to re-visit to Vietnam in the near future.

\section{REFERENCES}

[1] International visitors to Viet Nam in December and 12 months of 2013, Vietnam General Statistics Office.

[2] Vietnam Tourism Total Revenue 2000-2013, Ministry of Culture, Sport \& Tourism - Vietnam National Administration of Tourism.

[3] Y. Yoon and M. Uysal, "An examination of the effects of motivation and satisfaction on destination loyalty: A structural model," Tourism Management, vol. 26, no. 1, pp. 45-56, 2005.

[4] A. Tkaczynski, K. Hastings, and N. Beaumont, "Factors influencing repositioning of a tourism destination," in Proc. ANZMAC 2006 Conference Proceedings: Advancing Theory, Maintaining Relevance, 4-6 December 2006, Brisbane, Australia.

[5] G. Qiao, N. Chen, Y. Guan, and S. Kim, "Study on Chinese tourists' motivation and satisfaction to visit South Korea," International Journal of Tourism Sciences, vol. 8, no. 1, pp. 17-38, 2008.

[6] K. Kim, "Analysis of structural equation model for the student pleasure travel market: motivation, involvement, satisfaction, and destination loyalty," Journal of Travel \& Tourism Marketing, vol. 24, no. 4, pp. 297-313, 2008.

[7] S. Lee, S. Jeon, and D. Kim, "The impact of tour quality and tourist satisfaction on tourist loyalty: The case of Chinese tourists in Korea," Tourism Management, vol. 32, pp. 1115-1124, 2011.

[8] Y. Tang, "Travel motivation, destination image and visitor satisfaction of international tourists after the 2008 Wenchuan earthquake: A structural modelling approach," Asia Pacific Journal of Tourism Research, 2013.

[9] S. A. Pratminingsih, C. L. Rudatin, and T. Rimenta, "Roles of motivation and destination image in predicting tourist revisit intention: A case of Bandung - Indonesia," International Journal of Innovation, Management and Technology, vol. 5, no. 1, pp. 19-24, February 2014.

[10] A. Pizam, Y. Neumann, and A. Reichel, "Tourist satisfaction," Annals of Tourism Research, vol. 6, no. 2, pp. 195-197, 1979.

[11] D. Fodness, "Measuring tourist motivation," Annals of Tourism Research, vol. 21, no. 3, pp. 555-581, 1994.

[12] K. F. Backman, S. J. Backman, M. Uysal, and K. M. Sunshine, "Event tourism: an examination of motivations and activities," Festival Management and Event Tourism, vol. 3, no. 1, pp. 15-24, 1995.

[13] A. Beerli and J. D. Martı'n, "Factors influencing destination image," Annals of Tourism Research, vol. 31, no. 3, pp. 657-681, 2004.

[14] G. M. S. Dann, "Anomie ego-enhancement and tourism," Annals of Tourism Research, vol. 4, no. 4, pp. 184-194, 1977.

[15] G. M. S. Dann, “Tourist motivation: An appraisal," Annals of Tourism Research, vol. 8, no. 2, pp. 187-219, 1981.

[16] J. Crompton, "Motivations for pleasure vacations," Annals of Tourism Research, vol. 6, no. 4, pp. 408-424, 1979.

[17] M. Uysal and L. Hagan, "Motivations for pleasure travel and tourism," Encyclopedia of Hospitality and Tourism, New York: Van Nostrand Reinhold, pp. 798-810, 1993.

[18] M. Uysal and C. Jurowski, "An empirical testing of the push and pull factors of tourist motivations," Annals of Tourism Research, vol. 21, no. 4, pp. 844-846, 1993.

[19] S. S. Kim, C. Lee, and D. Klenosky, "The influence of push and pull factors at Korean National Parks," Tourism Management, vol. 24, no. 2, pp. 169-180, 2003. 
[20] D. Klenosky, "The pull of tourism destinations: A means-end investigation," Journal of Travel Research, vol. 40, no. 4, pp. 385-395, 2002.

[21] J. Gnoth, "Tourism motivation and expectation formation," Annals of Tourism Research, vol. 24, no. 2, pp. 283-304, 1997.

[22] X. You, J. O'Leary, A. Morrison, and G. Hong, "A cross-cultural comparison of travel push and pull factors: United Kingdom vs. Japan," International Journal of Hospitality \& Tourism Administration, vol. 1, no. 2, pp. 1-26, 2000.

[23] C. Chen and D. Tsai, "How destination image and evaluative factors affect behavioral intentions?" Tourism Management, vol. 28, no. 4, pp. 1115-1122, 2007.

[24] J. Kim, E. Suh, and H. Hwang, "A model for evaluating the effectiveness of CRM using the balanced scorecard," Journal of Interactive Marketing, vol. 17, no. 2, pp. 27-28, 2003.

[25] K. Chon, "Understanding recreational travelers' motivation, attitude and satisfaction," The Tourist Review, vol. 44, no. 1, pp. 3-7, 1989.

[26] S. McDowall, "International Tourist Satisfaction and Destination Loyalty: Bangkok, Thailand," Asia Pacific Journal of Tourism Research, vol. 15, no. 1, pp. 21-42, 2010.

[27] C. Chen and F. Chen, "Experience quality, perceived value, satisfaction and behavioral intentions for heritage tourists," Tourism Management, vol. 31, no. 1, pp. 29-35, 2010.

[28] P. Kotler, J. T. Bowen, and J. C. Makens, Marketing for Hospitality and Tourism, 4th ed. Upper Saddle River, NJ: Pearson Prentice Hall, 2006, ch. 1.

[29] R. L. Oliver, "A cognitive model of the antecedents and consequences of satisfaction decisions," Journal of Marketing Research, vol. 17, no. 4, pp. $460-469,1980$

[30] M. Kozak and M. Rimmington, "Tourist satisfaction with Mallorca, Spain, as an off-season holiday destination," Journal of Travel Research, vol. 38, no. 3, pp. 260-269, 2000.

[31] P. O. do Valle, J. A. Silva, J. Mendes, and M. Guerreiro, "Tourist satisfaction and destination loyalty intention: A Structural and categorical analysis," International Journal of Business Science and Applied Management, vol. 1, no. 1, pp. 25-44, 2006.

[32] X. Wang, J. Zhang, C. Gu, and F. Zhen, "Examining antecedents and consequences of tourist satisfaction: A structural modeling approach," Tsinghua Science and Technology, vol. 14, no. 3, pp. 397-406, 2009.

[33] S. Supitchayangkool, "The differences between satisfied/dissatisfied tourists towards service quality and revisiting Pattaya, Thailand," International Journal of Business and Management, vol. 7, no. 6, pp. $30-39,2012$.

[34] M. Fishbein and I. Ajzen, Belief, Attitude, Intention and Behavior: An Introduction to Theory and Research, Reading, Massachusetts: Addison-Wesley, 1975, ch. 7.

[35] J. Swan, "Disconfirmation of expectations and satisfaction with a retail service," Journal of Retailing, vol. 57, no. 3, pp. 49-66, 1981.

[36] I. Ajzen, "The theory of planned behavior," Organizational Behavior and Human Decision Processes, vol. 50, no. 2, pp. 179-211, 1991.

[37] M. Fishbein and M. Manfredo, "A theory of behavior change," in Influencing Human Behavior: Theory and Applications in Recreation, Tourism, and Natural Resources Management, M. Manfredo, Ed. Champaign, IL: Sagamore Publishing, 1992, pp. 29-50.

[38] S. Baloglu, "A path analytic model of visitation intention involving information sources, socio-psychological motivations, and destination image," Journal of Travel \& Tourism Marketing, vol. 8, no. 3, pp. $81-90,2000$

[39] J. Kuhl and J. Beckmann, Action Control from Cognition to Behavior, Berlin: Springer-Verlag, 1985.

[40] G. McDougall and H. Munro, "Scaling and attitude measurement in travel and tourism," in Travel, Tourism and Hospitality Research, B. Ritchie and C. Goeldner, Eds. 2nd ed. New York: John Wiley \& Sons, Inc, 1994, pp. 115-129.

[41] J. T. Bowen and S. Chen, "The relationship between customer loyalty and customer satisfaction," International Journal of Contemporary Hospitality Management, vol. 13, no. 5, pp. 213-217, 2001.

[42] A. L. S. Lau and B. McKercher, "Exploration versus acquisition: A comparison of first time and repeat visitors," Journal of Travel Research, vol. 42, no. 3, pp. 279-285, 2004.

[43] T. V. Vuuren, M. Roberts-Lombard, and E. V. Tonder, "Customer satisfaction, trust and commitment as predictors of customer loyalty within an optometric practice environment," Southern African Business Review, vol. 16, no. 3, pp. 81-96, 2012.

[44] B. G. Tabachnick and L. S. Fidell, Using multivariate statistics, 4th ed. New York: HarperCollins, 2001.

[45] J. F. Jr. Hair, W. C. Black, B. J. Babin, R. E. Anderson, and R. L. Tatham, Multivariate Data Analysis, 6th ed. New Jersey: Prentice Hall, 2006.

[46] J. Pallant, SPSS Survival Manual: A Step by Step Guide to Data Analysis Using SPSS for Windows, 3rd ed. Open University Press, 2007.

[47] J. K. Preacher and A. F. Hayes, "Asymptotic and resampling strategies for assessing and comparing indirect effects in multiple mediator models," Behavior Research Methods, vol. 40, no. 3, pp. 879-891, 2008.

[48] J. K. Preacher and A. F. Hayes, "SPSS and SAS procedures for estimating indirect effects in simple mediation models," Behavior Research Methods, Instruments, \& Computers, vol. 36, no. 4, pp. 717-731, 2004.

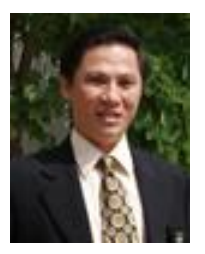

Mai Ngoc Khuong is a lecturer and researcher of School of Business Administration, International University, Vietnam National University, Ho Chi Minh City. He has bachelor degree in tourism and hospitality management, master of science degree in leisure, tourism and environment at Wageningen University, The Netherlands, and $\mathrm{PhD}$ degree in development management at School of Public Administration of the National Institute of Development Administration (NIDA), Bangkok, Thailand.

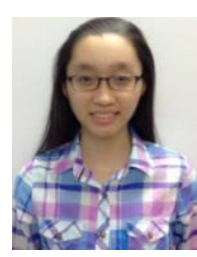

Huynh Thi Thu Ha is a student of School of Business Administration, International University, Vietnam National University, Ho Chi Minh City. 